\title{
Mitochondrial mutagenesis in BCR-ABL1-expressing cells sensitive and resistant to imatinib
}

\author{
Janusz Blasiak ${ }^{\circledR}$, Grazyna Hoser $^{2}$, Jolanta Bialkowska-Warzecha ${ }^{3}$, Elzbieta Pawlowska ${ }^{4}$ and \\ Tomasz Skorski ${ }^{5}$
}

1Department of Molecular Genetics, University of Lodz, Łódź, Poland; 2Department of Flow Cytometry, Medical Center for Postgraduate Education, Warsaw, Poland; ${ }^{3}$ Department of Infectious and Liver Diseases, Medical University of Lodz, Łódź, Poland; ${ }^{2}$ Department of Orthodontics, Medical University of Lodz, Łódź, Poland; ${ }^{5}$ Department of Microbiology and Immunology, School of Medicine, Temple University, Philadelphia, PA 19140, USA

\begin{abstract}
Imatinib revolutionized the treatment of chronic myeloid leukemia (CML) with the expression of the BCR-ABL1 tyrosine kinase, but imatinib resistance is an emerging problem. Imatinib can hinder the inhibitory effects of BCR-ABL1 on mitochondrial apoptotic pathway, so mitochondrial mutagenesis can be important for its action. To explore the mechanisms of imatinib resistance we created a mouse-derived CML model cells consisting of parental 32D cells (P) and cells transfected with the $B C R-A B L 1$ gene (S cells) or its variants with the $\mathrm{Y} 253 \mathrm{H}$ or T315I mutations (253 and 315 cells, respectively), conferring resistance to imatinib. A fraction of the $S$ cells was cultured in increasing concentrations of imatinib, acquiring resistance to this drug (AR cells). The 253, 315 and $A R$ cells, in contrast to $S$ cells, displayed resistance to imatinib. We observed that the T315I cells displayed greater extent of $\mathrm{H}_{2} \mathrm{O}_{2}$-induced mtDNA damage than their imatinib-sensitive counterparts. No difference in the sensitivity to UV radiation was observed among all the cell lines. A decrease in the extent of $\mathrm{H}_{2} \mathrm{O}_{2}$-induced mtDNA damage was observed during a 120 -min repair incubation in all cell lines, but it was significant only in imatinib-sensitive and T315I cells. No difference in the copy number of mtDNA and frequency of the 3,867-bp deletion was observed and genotoxic stress induced by $\mathrm{H}_{2} \mathrm{O}_{2}$ or UV did not change this relationship. In conclusion, some aspects of mtDNA mutagenesis, including sensitivity to oxidative stress and DNA repair can contribute to imatinib resistance in BCR-ABL1-expressing cells.
\end{abstract}

Key words: Imatinib, chronic myeloid leukemia, $B C R-A B L 1$ gene

Received: 15 September, 2015; revised: 16 December, 2015; accepted: 18 December, 2015; available on-line: 12 January, 2016

\section{INTRODUCTION}

Imatinib (imatinib mesylate, STI571, Gleevec), a tyrosine kinase inhibitor (TKI), has revolutionized the therapy of chronic myeloid leukemia (CML) and is a paradigm for cancer targeted therapies (Druker 2008). It targets the ATP-binding site in the BCR-ABL1 tyrosine kinase, present in CML cells and responsible for cancer phenotype, inhibiting phosphorylation of its substrates. The main mode of anti-leukemic action of imatinib is inhibition of the pro-survival signaling pathways activated by BCR-ABL1. Although imatinib is not free of unwanted side effects, the main problem with its use is the resist- ance, which can be primary or secondary. Primary resistance is present at the moment of CML diagnosis and can be augmented by mechanisms, which are poorly known (reviewed in Bixby \& Talpaz, 2011). Secondary resistance appears after initial responsiveness to imatinib and can be associated with mutations in the BCR-ABL1 gene. The problem of imatinib resistance has been only partly resolved by second- and third- generations of TKIs and supplementation of imatinib-based therapy with other drugs modulating pro-survival pathways activated by BCR-ABL1 (reviewed in Lipton et al., 2015).

Although BCR-ABL1 confers CML phenotype by inhibiting apoptosis and stimulating cell proliferation, the mechanisms of progression of the disease from longlasting, often syndrome-free chronic phase (CP) through acceleration phase (AP) to usually fatal blast crisis (BP) are not fully known. The final stage of the disease progression is associated with acquiring TKIs resistance. Therefore, the mechanism of imatinib resistance, or more generally - TKIs resistance, can be a key mechanism of CML relapse and recurrence.

CML cells, like almost all other cancer cells, display genomic instability. We and others showed that this instability is associated with the production of reactive oxygen species (ROS) and unfaithful DNA repair stimulated by BCR-ABL1 (Brady et al., 2011; Griaud et al., 2012; Nieborowska-Skorska et al., 2012, 2013, 2014; Slupianek et al., 2013). Moreover, genomic instability of CML cells increases with the disease progression, so it can be associated with imatinib resistance. We showed that increased ROS production by mutated BCR-ABL1 could be linked with imatinib resistance (Koptyra et al., 2006).

The term genomic instability is usually related to the nuclear genome. However, if the instability of CML cells is associated with an increased ROS production, and we showed that Rac2 GTPase altered the mitochondrial electron transport and generated ROS in both stem and progenitor leukemic cells, then mtDNA can be in front-line of ROS attack and its instability may significantly contribute to genomic instability of CML cells (Nieborowska-Skorska et al., 2012). It is particularly interesting in the context of imatinib resistance as the drug blocks

e-mail: jblasiak@biol.uni.lodz.pl

Abbreviations: AP, acceleration phase; $\mathrm{BCl}-\mathrm{xL}$, B-cell lymphoma extra large; $B E R$, base excision repair; $B C R$, the breakpoint cluster region gene; $B C R-A B L 1$, fusion tyrosine kinase; $B P$, blast phase; $c-A B L 1$, the Abelson proto-oncogene; CCK-8, cell counting kit; $C M L$, chronic myeloid leukemia; CP, chronic phase; ETC, electron transport chain; NER, nucleotide excision repair; ROS, reactive oxygen species; TKI, tyrosine kinase inhibitor 
BCR-ABL1 in anti-apoptotic pathways, so mitochondria, along with mtDNA, can be important for this effect. In our previous work we showed that imatinib resistance was associated with increased ROS production and DNA damage induced by doxorubicin, an anticancer drug inducing DNA double-strand breaks and other DNA damage (Blasiak et al., 2015). Moreover, we showed also that the expression of some apoptosis-related mitochondrial genes could be different in imatinib-sensitive and -resistant cells exposed to UV radiation (Synowiec et al., 2015). In turn, imatinib-resistant cells were reported to display several mitochondrial dysfunctions associated with an increased ROS production in mitochondria (Kluza et al., 2011). These extra ROS could damage mtDNA, which can accelerate the mitochondrial viscous cycle, leading to genomic instability. All these data suggest that mutagenesis of mtDNA can play an important role in imatinib resistance in CML cells. To explore this subject further, in the present work we investigated the response of mtDNA to $\mathrm{H}_{2} \mathrm{O}_{2}$ and UV in BCR-ABL1-expressing cells sensitive and resistant to imatinib. $\mathrm{H}_{2} \mathrm{O}_{2}$ produces ROS, which can damage mtDNA contributing to genome instability. The main DNA damage induced by UV are cyclobutane pyrimidine dimers and (6-4) photoproducts, which are primarily removed by nucleotide excision repair (NER) in the nucleus, but this DNA repair system is considered not to operate in mitochondria. Therefore, analysis of UV-induced DNA damage in mitochondria can facilitate the assessment of the general role of NER in imatinib resistance mechanism.

\section{MATERIALS AND METHODS}

Cells, viability and treatment. Murine $32 \mathrm{D}$ cells were transfected with the BCR-ABL1 gene or its mutated $\mathrm{Y} 253 \mathrm{H}$ or T315I variants as described previously (Slupianek et al., 2002). Some cells expressing non-mutated $B C R-A B L 1$, were cultured in increased concentrations of imatinib to acquire resistance to this drug up to $1.0 \mathrm{mM}$. This was achieved by $\mathrm{S}$ cells incubation with $0.01 \mu \mathrm{M}$ imatinib for 3 weeks with survival rate about $80 \%$. The incubation was continued with $0.05 \mu \mathrm{M}$ imatinib and this process was repeated with growing concentrations of imatinib until not less than $50 \%$ of cells survived at $1 \mathrm{mM}$ imatinib. Consequently, we used parental 32D cell line $(\mathrm{P})$ and four 32D BCR-ABL1-transfected cell lines: cells sensitive to imatinib (S), imatinib-resistant cells with the mutation in the BCR-ABL1 gene $(\mathrm{Y} 253 \mathrm{H}$ and T315I) and cells with acquired resistance to imatinib (AR). The cells were cultured in IMDM medium supplemented with $2 \mathrm{mM}$ L-glutamine, $100 \mathrm{U} / \mathrm{ml}$ penicillin, $100 \mu \mathrm{g} / \mathrm{ml}$ streptomycin, $10 \%$ fetal bovine serum and maintained at $37^{\circ} \mathrm{C}$ in $5 \% \mathrm{CO}_{2}$ atmosphere at $100 \%$ humidity. The medium of parental cells was supplemented with $1 \mathrm{ng} / \mathrm{ml}$ of interleukin-3.

To assess sensitivity/resistance to imatinib, the cells were incubated at $37^{\circ} \mathrm{C}$ with imatinib for $24 \mathrm{~h}$ and cell viability was determined with a tetrazolium salt using the Cell Counting Kit-8 (CCK-8) (Sigma-Aldrich).

Total DNA from the cells was isolated with QIAamp DNA Mini Kit (Qiagen, Hilden, Germany). The concentration and purity of DNA were determined spectrophotometrically.

To evaluate mtDNA damage and repair as well as mtDNA copy number during genotoxic stress, the cells were incubated for $30 \mathrm{~min}$ at $37^{\circ} \mathrm{C}$ with $50 \mu \mathrm{M} \mathrm{H}_{2} \mathrm{O}_{2}$ or were irradiated with $254 \mathrm{~nm}$ UV radiation at room
Table 1. Sequence of primers used to amplify fragments of mitochondrial DNA by semi-long real-time PCR

\begin{tabular}{ll}
\hline Fragment (length) & Primers $\left(5^{\prime} \rightarrow 3^{\prime}\right.$, forward and reverse) \\
\hline Shorter $(82 \mathrm{bp})$ & $\begin{array}{l}\text { AACCCACGATCAACTGAAGC } \\
\text { GTACGATGGCCAGGAGGATA }\end{array}$ \\
\hline Longer $(1054 \mathrm{bp})$ & $\begin{array}{l}\text { ATCCTCACCTCAGCCAACAA } \\
\text { TGAGGACTGGAATGCTGGT }\end{array}$ \\
\hline Reference $(82 \mathrm{bp})$ & $\begin{array}{l}\text { AGAATGGGAAGCCGAACATA } \\
\text { CCGTTCTTCAGCATTGGAT }\end{array}$ \\
\hline
\end{tabular}

temperature using UVC-6-12 lamp (NeoLab, Heidelberg, Germany) with dose rate of $0.12 \mathrm{Wm}^{-2} \mathrm{~s}^{-1}$.

Mitochondrial DNA damage and repair and data analysis. Mitochondrial DNA damage was quantified by semi-long real-time quantitative PCR as described elsewhere (Ballinger et al., 1999; Rothfus et al., 2010). In this reaction, two mtDNA fragments of length about 1000 and $80 \mathrm{bp}$ are amplified. The longer amplicon is the target for DNA-damaging agents, whereas the shorter one is unlikely to be affected by DNA damage and enables normalization of the amount of PCR product to relative copy number. In this reaction, any mtDNA lesion causing block of DNA polymerase results in a decrease in the amount of amplicons of the target fragment in mtDNA. The primer sequences are given in Table. 1. All primers were synthesized by Sigma. An 82 bp fragment of the mouse beta-2 microglobulin gene was used as a reference.

Each reaction was carried out in a thermal cycler model CFX96 Real-Time PCR Detection System (BioRad Laboratories, Hercules, CA, USA) in a total volume of $10 \mathrm{ml}$ with $1 \times$ Maxima SYBR Green QPCR Master Kit (Thermo Scientific, West Palm Beach, FL, USA) with $500 \mathrm{ng}$ of each primer and $100 \mathrm{ng}$ of DNA template. The amplification reaction consisted of the preinitial denaturation step at $95^{\circ} \mathrm{C}$ for $10 \mathrm{~min}$ followed by 40 cycles of $15 \mathrm{~s}$ at $95^{\circ} \mathrm{C} / 30 \mathrm{~s}$ at $62^{\circ} \mathrm{C} / 75 \mathrm{~s}$ at $72^{\circ} \mathrm{C}$ for the long product, whereas for the short products amplification had a preincubation phase at $95^{\circ} \mathrm{C}$ for $10 \mathrm{~min}$ and 40 cycles of $15 \mathrm{~s}$ at $95^{\circ} \mathrm{C} / 30 \mathrm{~s}$ at $59^{\circ} \mathrm{C} / 30 \mathrm{~s}$ at $72^{\circ} \mathrm{C}$. Each sample was analyzed in triplicate.

Repair of mtDNA damage was determined by the measurements of the extent of mtDNA damage at time 0 (the beginning of the repair incubation) and 30,60 and 120 min thereafter.

DNA damage in cell exposed to $\mathrm{H}_{2} \mathrm{O}_{2}$ or UV radiation was compared to control, non-exposed cells. Relative mtDNA damage $(D)$ was expressed as the number of mtDNA lesions per $10 \mathrm{~kb}$ DNA and was measured by calculating the difference $\Delta C_{t}$ for longer and shorter fragments for the $2^{-\Delta \Delta C t}$ method (the comparative $C_{t}$ method) in correlation with the size of longer fragment after amplification according to the equation:

$$
D=\frac{\left.1-2^{-(s i}-\omega_{S}\right)}{L}
$$

where $\Delta_{1}$ and $\Delta_{\mathrm{s}}$ are $\Delta \mathrm{C}_{\mathrm{t}}$ for longer and shorter fragments, respectively, $L$ is the size of longer fragment in bp (Schmittgen \& Livak, 2008; Hou et al., 2010).

The 3,867-bp deletion in mtDNA. Quantitative detection of the 3,897-bp deletion was performed by quantitative real-time PCR with TaqMan fluorescence quenching probes essentially as described by Kazachkova et al. (Kazachkova et. al., 2013). Briefly, the assay is based on the amplification of fragments of all mtDNA mol- 
Table 2. Sequence of primers used to determine the number of mtDNA molecules with the 3,867-bp deletion by real-time PCR

\begin{tabular}{ll}
\hline Fragment specificity & $\begin{array}{l}\text { Primers }\left(5^{\prime} \rightarrow 3^{\prime}, \text { forward }\right. \\
\text { and reverse })\end{array}$ \\
\hline All mtDNA molecules & $\begin{array}{l}\text { TCGCCACTCTATAACAGCTATG } \\
\text { AATGCTAGGCGTTTGATTGG }\end{array}$ \\
\hline $\begin{array}{l}\text { mtDNA molecules without } \\
\text { the 3,867-bp deletion }\end{array}$ & $\begin{array}{l}\text { TGTACCCACGCATTCTTCAA } \\
\text { AATGCTAGGCGTTTGTTGG }\end{array}$ \\
\hline
\end{tabular}

ecules (primers specific to a region outside the deletion) and molecules without deletions (primers within the deletion). The former, after normalization to the nuclear $G A P D H$ gene, provides information on the number of copy of mtDNA. The difference between the number of all mtDNA molecules and of molecules without the deletion indicates the number of molecules with the 3,867-bp deletion. The sequence of primers are listed in Table 2.

Each reaction was run on the CFX96 thermal cycler in a total volume of $10 \mathrm{ml}$ containing $10 \mathrm{ng}$ template DNA, 5 pmol of each primer and probe, 1 U of DNA polymerase, $1.25 \mathrm{mM} \mathrm{MgCl}_{2}$ and $0.2 \mathrm{mM}$ of each dNTP. Amplification conditions were: initial $10 \mathrm{~min}$ denaturation at $95^{\circ} \mathrm{C}$, followed by 40 cycles at $95^{\circ} \mathrm{C}$ for $15 \mathrm{~s}$ and at $60^{\circ} \mathrm{C}$ for $60 \mathrm{~s}$. Each sample was run in triplicate.

Statistical analysis. All values in this study were expressed as mean \pm S.E.M. and the differences between means were evaluated by the Student's $t$ test. The data were analyzed using the STATISTICA (StatSoft, Tulsa, OK, USA) statistical package.

\section{RESULTS}

Imatinib resistance. The parental 32D cells $(\mathrm{P})$ were almost insensitive to $1 \mu \mathrm{M}$ imatinib as their relative viability was about $87 \%$ (Fig. 1). For cells transfected with non-mutated $B C R-A B L 1$ (S) the survival rate after imatinib treatment was less than $20 \%$, so they were further considered as imatinib-sensitive. The viability of cells with the $\mathrm{Y} 253 \mathrm{H}$ and T315I mutations in the BCR/ ABL1 gene was over $70 \%$ and of the AR cells - about $50 \%$, so we considered these cells as imatinib-resistant.

Damage to mtDNA. Neither $\mathrm{H}_{2} \mathrm{O}_{2}$ nor UV radiation changed substantially the viability of the cells (results not shown). $\mathrm{H}_{2} \mathrm{O}_{2}$ evoked pronounced damage to mtDNA in all cell lines (Fig. 2). There was no difference between the extent of mtDNA damage in parental and BCR-ABL1-expressing cells. All imatinib-resistant cell lines displayed higher extent of DNA damage than their imatinib-sensitive counterparts, but this relationship was rather of border-line significance. All cell lines presented similar, moderate sensitivity to UV radiation. Although the sensitivity to imatinib seemed to be negatively correlated with $\mathrm{H}_{2} \mathrm{O}_{2}$-induced mtDNA damages and the T315I cells appeared to be the least sensitive to UV, these relationships are not statistically significant.

Repair of mtDNA. The kinetics of mtDNA repair in the studied cell lines exposed to $\mathrm{H}_{2} \mathrm{O}_{2}$ or UV radiation is presented in Fig. 3. There was an essential difference in the reaction of all cell lines to $\mathrm{H}_{2} \mathrm{O}_{2}$ and UV. The extent of mtDNA damage in cells exposed to $\mathrm{H}_{2} \mathrm{O}_{2}$ decreased after a $120-\mathrm{min}$ repair incubation, although the difference between DNA damage at $120 \mathrm{~min}$ and zero was not always statistically significant (a border-line significance for $\mathrm{P}(p=0.061)$ and 253 lines $(p=0.58))$. There was not any difference in the extent of mtDNA dam-

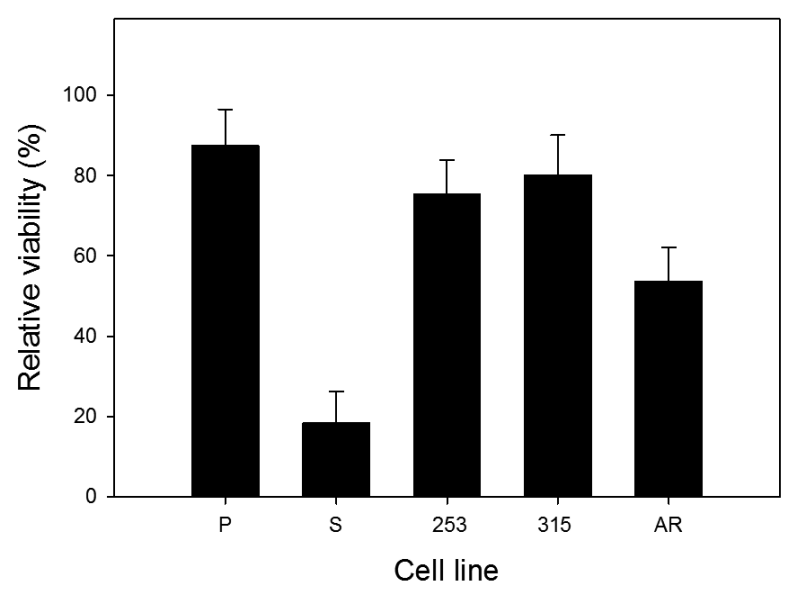

Figure 1. Relative viability of mouse 32D cells incubated for $24 \mathrm{~h}$ with $1 \mu \mathrm{M}$ imatinib at $37^{\circ} \mathrm{C}$.

Parental cells $(P)$ were transfected with the $B C R-A B L 1$ gene in its normal form (S) or with $\mathrm{Y} 253 \mathrm{H}$ (253) and T315I (315) mutation. Some $S$ cells were cultured in a growing concentration of imatinib (AR) prior to viability determination. The viability was determined with Cell Counting Kit-8. Each measurement was performed in triplicate; error bars denote S.E.M.

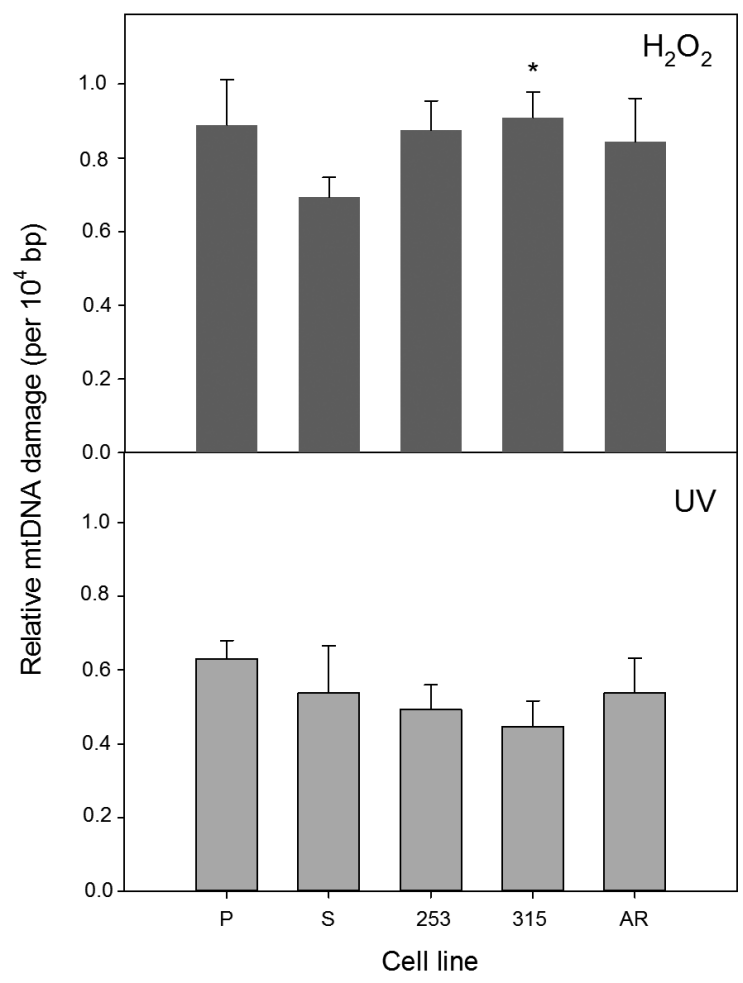

Figure 2. $\mathrm{H}_{2} \mathrm{O}_{2}$ - and UV-induced damage to mtDNA in mouse 32D cell lines: parental $(P)$ and transfected with the $B C R-A B L 1$ gene: sensitive (S) and resistant to imatinib (253, 315, AR).

The resistance resulted either from the $\mathrm{Y} 253 \mathrm{H}$ or $\mathrm{T} 315 \mathrm{I}$ mutation in the $B C R-A B L 1$ gene ( 253 and 315 , respectively) or from incubation of sensitive cells with increasing concentration of imatinib (AR). Cells were incubated $30 \mathrm{~min}$ at $37^{\circ} \mathrm{C}$ with $\mathrm{H}_{2} \mathrm{O}_{2}$ at $50 \mu \mathrm{M}$ or were irradiated with UV light at $35 \mathrm{~J} / \mathrm{m}^{2}$ at room temperature with a dose rate of $0.12 \mathrm{Wm}^{-2} \mathrm{~s}^{-1}$ and $\mathrm{mtDNA}$ damage was quantified by semi-long real-time PCR. Error bars denote S.E.M., $\mathrm{n}=3$ for each measurement; ${ }^{*} p<0.05$ as compared with $S$ line.

age at the beginning and at the end of the repair incubation in cells exposed to UV radiation. The kinetics of mtDNA repair in $\mathrm{H}_{2} \mathrm{O}_{2}$-pretreated cells was similar and there were slight, statistically insignificant differences be- 


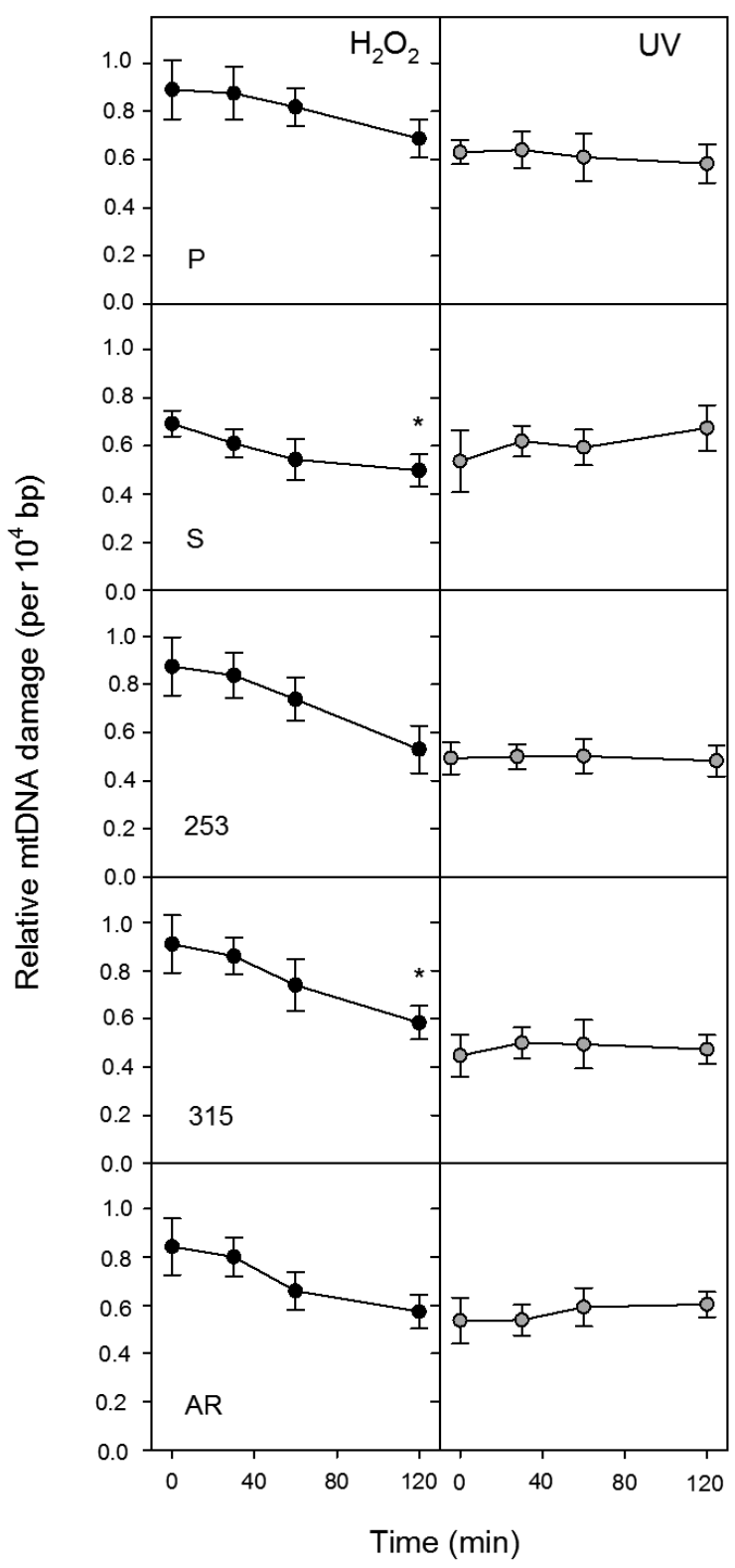

Figure 3. mtDNA repair in mouse 32D cell lines: parental $(P)$ and transfected with the $B C R-A B L 1$ gene: sensitive $(S)$ and resistant to imatinib $(253,315, A R)$.

The resistance resulted either from the $\mathrm{Y} 253 \mathrm{H}$ or $\mathrm{T} 315 \mathrm{I}$ mutation in the $B C R-A B L 1$ gene ( 253 and 315 , respectively) or from incubation of sensitive cells with increasing concentration of imatinib (AR). Cells were challenged with $\mathrm{H}_{2} \mathrm{O}_{2}\left(30 \mathrm{~min}, 37^{\circ} \mathrm{C}\right.$ ) at $50 \mu \mathrm{M}$ (left panels) or UV radiation with a dose rate $0.12 \mathrm{Wm}^{-2} \mathrm{~s}^{-1}$ (right panels) and mtDNA damage was quantified by semi-long real-time PCR at 0 (immediately after the exposure), 30, 60 and $120 \mathrm{~min}$ thereafter. Error bars denote S.E.M., $\mathrm{n}=3$ for each measurement, ${ }^{*} p<0.05$ as compared with the time 0 .

tween imatinib-resistant and -sensitive cells, which is best illustrated in the case of 253 and S cells. Apparently, it seems that in the former the rate of the mtDNA repair is higher than in case of the latter.

Copy number of mtDNA. Figure 4 presents the relative mean copy number of mtDNA in cells exposed to $\mathrm{H}_{2} \mathrm{O}_{2}$ or UV radiation as compared with non-exposed cells. There was not any difference in the copy number between imatinib-resistant and -sensitive cells. Therefore, neither $\mathrm{H}_{2} \mathrm{O}_{2}$ nor UV did induce degradation of $\mathrm{mtDNA}$ in any kind of cells.

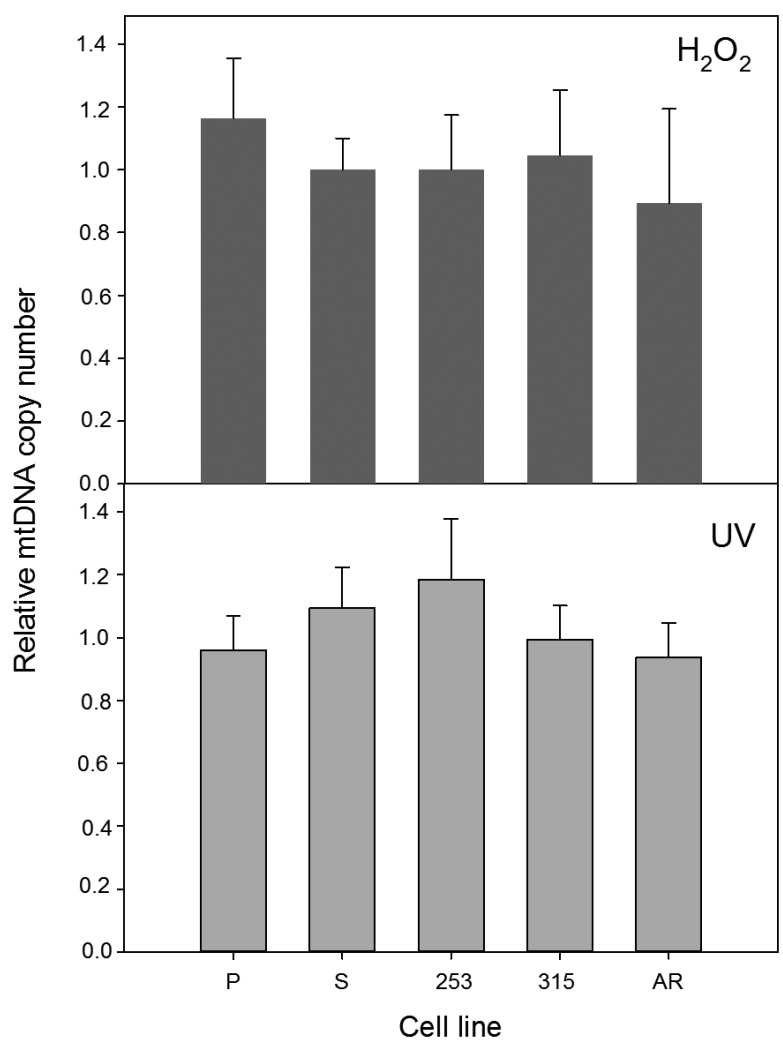

Figure 4. Relative mtDNA copy number in mouse 32D cell lines: parental $(P)$ and transfected with the $B C R-A B L 1$ gene: sensitive (S) and resistant to imatinib $(253,315, \mathrm{AR})$.

The resistance resulted either from the $\mathrm{Y} 253 \mathrm{H}$ or $\mathrm{T} 315 \mathrm{I}$ mutation in the BCR-ABL1 gene (253 and 315 , respectively) or incubation the sensitive cells with increasing concentrations of imatinib (AR). Cells were challenged with $\mathrm{H}_{2} \mathrm{O}_{2}\left(30 \mathrm{~min}, 37^{\circ} \mathrm{C}\right.$ ) at $50 \mu \mathrm{M}$ (upper panel) or UV radiation with a dose rate $0.12 \mathrm{Wm}^{-2} \mathrm{~s}^{-1}$ (lower panel) mtDNA copy number was calculated by quantitative real-time PCR of 82-bp fragments of the mitochondrial NADH dehydrogenase, subunit 2 (ND2) gene and the nuclear beta-2 microglobulin (B2M) gene. The ratio of copy number in cells exposed to either $\mathrm{H}_{2} \mathrm{O}_{2}$ or UV radiation and unexposed cells is presented. Error bars denote S.E.M., $\mathrm{n}=3$ for each measurement.

The 3,867 deletion in mtDNA. No statistically significant difference in relative number of $\mathrm{mtDNA}$ copies with the 3,867-bp deletion between the cell lines was observed (Fig. 5). Neither the exposure to $\mathrm{H}_{2} \mathrm{O}_{2}$, nor UV irradiation affected this number.

\section{DISCUSSION}

After the initial success of imatinib, resistance to this drug or, more generally, to TKIs, has become an emerging problem and is one of the most serious obstacles of imatinib-based targeted cancer therapy. Several mechanisms can underline imatinib resistance and some of them are partly known, stimulating modifications of CML therapy. As mentioned above, these modifications include first of all introduction of second- and third-generations of TKIs as well as supplementation of imatinib-based therapy with other drugs modulating imatinib effect. As BCR-ABL1 enhances ROS production, DNA damage and repair is of a special significance in BCR-ABL1-positive cells. Because mitochondria primarily produce intracellular ROS due to the activity of electron transport chain (ETC), mtDNA is particularly exposed to ROS. As the repair of mtDNA takes place mainly in the immediate vi- 


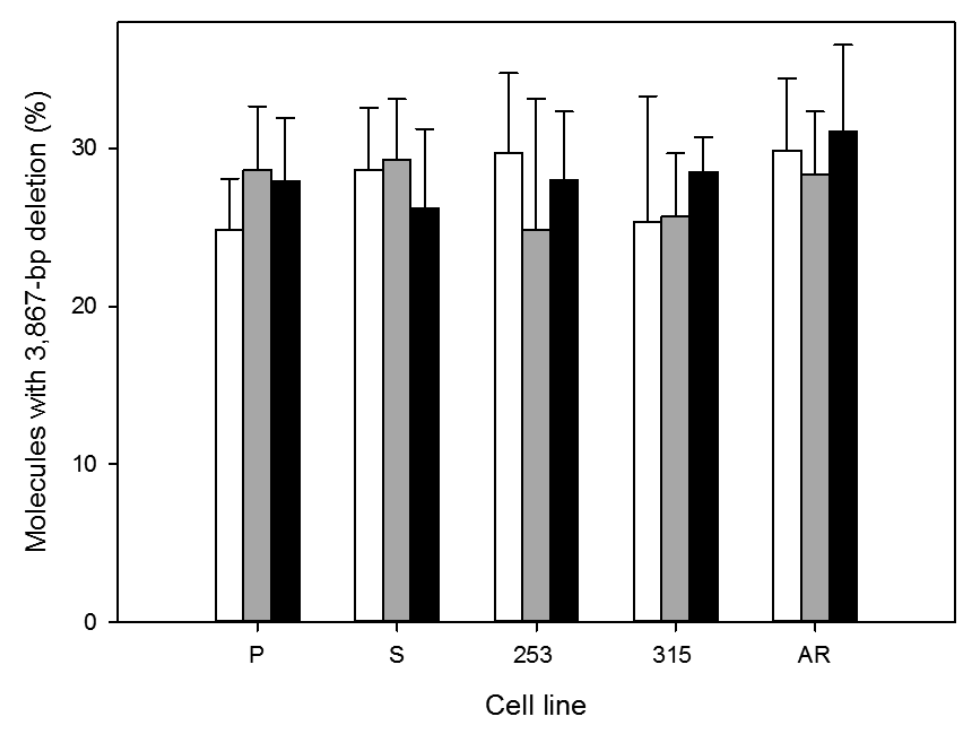

Figure 5. Relative mean number of mtDNA copies with the 3,867-bp deletion in mouse 32D cell lines: parental (P) and transfected with the $B C R-A B L 1$ gene: sensitive (S) and resistant to imatinib $(253,315, A R)$ exposed to $\mathrm{H}_{2} \mathrm{O}_{2}$ at $50 \mu \mathrm{M}$ for $30 \mathrm{~min}$ at $37^{\circ} \mathrm{C}$ (gray bars) or UV radiation with a dose rate $0.12 \mathrm{Wm}^{-2} \mathrm{~s}^{-1}$ (black bars) as compared with non-exposed cells (white bars).

Imatinib resistance resulted either from the $\mathrm{Y} 253 \mathrm{H}$ or $\mathrm{T} 315 \mathrm{I}$ mutation in the $B C R$ $A B L 1$ gene ( 253 and 315 , respectively) or incubation of the sensitive cells with increasing concentrations of imatinib (AR). The number of mtDNA molecules with the deletion was determined by quantitative real-time PCR of fragments of mtDNA without the deletion and all mtDNA molecules. The number of mtDNA molecules without the deletion was then subtracted from the number of all mtDNA copies and divided by it. Error bars denote S.E.M., $n=3$ for each measurement.

cinity of ETC proteins in the inner mitochondrial membrane, it can be error-prone due to the presence of ROS attacking DNA repair proteins (Gredilla et al., 2010). The vulnerability of mtDNA to damage is also important in the light of imatinib mechanism of action - blocking the antiapoptotic action of BCR-ABL1. Because the mitochondrial apoptotic pathway is the key route of apoptotic signaling, damage to mtDNA can interfere with this process and thus modulate imatinib action.

Although the amount of mtDNA in a human cell can be quite high due to a high number of mitochondria in some kind of cells, the mechanisms of mtDNA repair are much less effective than those operating in the nucleus. The most striking difference between DNA repair in the nucleus and mitochondria is the lack of mitochondrial NER, at least the one operating in a nucleus-like fashion. Some reports suggest the presence of certain proteins in the organelle, including Cockayne syndrome proteins (CSA and CSB), which in the nucleus are involved in transcription-coupled NER (Kamenisch \& Berneburg, 2013). Moreover, a possible link between NER-associated CS proteins and mitochondrial base excision repair (BER) is suggested, but this issue still needs detailed studies. It was shown that CSA and CSB proteins are associated with human mitochondrial 8-oxoguanine glycosylase, the crucial element of antioxidant defense (Kamenish et al., 2010, Kamenisch \& Berneburg 2013). Lastly, the presence of the XPD, an important NER protein, in the inner mitochondrial membrane was reported, but its involvement in putative mitochondrial NER is uncertain (Liu et al., 2015).

If the extent of mtDNA damage exceeds the repair capacity of the cell, mtDNA is directed to degradation (Kang \& Hamasaki, 2002). DNA damage tolerance mechanisms have not been reported in animal mitochondria. Therefore, if NER is not operating in mitochondria, induction of NER-specific DNA damages can lead to the accumulation of mtDNA lesions, increase in genomic instability and eventually to degradation of mtDNA. That is why we chose UV radiation as the DNA-damaging factor, because its main products - pyrimidine dimers and (6-4)photoproducts, are removed in the nucleus by NER.

We used cells, which were derived from the 32D cell line. We modified the parental $32 \mathrm{D}$ cells to express the BCR-ABL1 kinase in its native type and two mutated forms, conferring imatinib resistance. Additionally, cells with non-mutated BCR-ABL1 were incubated in escalating doses of imatinib to acquire resistance to this drug. The status of the AR cells is rather uncertain in that sense that they form a highly dynamic system, so their usefulness in the investigation of the mechanisms of biochemical processes is rather limited. However, they were included in our project as they correspond to the situation when CML patients, initially sensitive to imatinib, become resistant due to mutations in the BCR-ABL1 gene and other mechanisms. Therefore, we created a CML model cellular system, representing imatinib-sensitive and -resistant cases. Certainly, using a single cell system is a limitation of our study, but we do not know other such system, which would be available for us. Using primary cells from CML patients is an option, but it requires enrolling many patients and much time to collect adequate number of samples. Our research can be viewed as an introduction to the field, along with other studies we recently performed (Blasiak et al., 2015; Synowiec et al., 2015).

In the present work we showed, that there was not any difference in the extent of $\mathrm{mtDNA}$ damage induced by UV radiation among the cell lines we used (Fig. 2). The assay we employed - synthesis of new DNA fragment on a template from exposed cells is sensitive to UV-induced damage, as both pyrimidine dimers and (6-4)photoproducts inhibit DNA polymerase movement along the template. Therefore, we can speculate that NER could not be involved in the mechanisms of imatinib resistance in BCR-ABL1-expressing cells. The imatinib-resistant T315I cells displayed an increased extent of mtDNA damage after $\mathrm{H}_{2} \mathrm{O}_{2}$ treatment compared to their imatinib-sensitive counterparts (Fig. 2). This can be related to increased genomic instability associated with imatinib-resistance. $\mathrm{H}_{2} \mathrm{O}_{2}$ induces a variety of DNA damages, but at moderate concentrations, oxidative modifications to the DNA bases are the most frequently occurring DNA lesions. These are removed by base excision repair (BER), a pathway which is likely the most effectively operating DNA repair system in mitochondria. However, we did not observe any significant difference in mtDNA damage induced by $\mathrm{H}_{2} \mathrm{O}_{2}$ between other imatinibresistant cells and their sensitive counterparts.

The T315I and Y253H lines displayed similar resistance to imatinib in our experiments, but they represent two different mutations (Miething et al., 2006). The T315I mutation, most frequently occurring in imatinib-resistant CML patients, directly impairs imatinib binding as it is located at the drug-contact side. In turn, the Y253H mutation is located at the nucleotide-binding loop of BCR-ABL1, impairing the optimal conformation for imatinib binding. Therefore, these two mutations can differently influence the conformation of the BCR-ABL1 kinase, which, in turn, can differently affect its role in DNA repair (Skorski, 2002). 
Although there were some border-line significance differences in DNA repair after $\mathrm{H}_{2} \mathrm{O}_{2}$ treatment, all cell lines displayed similar kinetics of $\mathrm{mtDNA}$ repair and, in general, repaired their DNA during this 120-min incubation (Fig. 3). However, repair kinetics after $\mathrm{H}_{2} \mathrm{O}_{2}$ differed from that representing repair of UV-induced $\mathrm{mtDNA}$ damage, confirming no NER involvement.

Although no effective repair of UV-induced mtDNA damage was observed, we did not observe changes in the mtDNA copy number either (Fig. 4), therefore possible lack of NER did not result in mtDNA degradation due to inability to repair pyrimidine dimers and (6-4) photoproducts.

There was no difference in the occurrence of the common 3,867-bp deletion between resistant and sensitive cells and genotoxic treatment did not change this relationship (Fig. 5). We explain these results by relatively mild conditions of the treatment and the nature of this mutation, as the mechanism of its generation is different from the mechanisms underlying point mutations, most frequently associated with genomic instability of cancer cells.

In conclusion, BCR-ABL1 imatinib-resistant cells can display an enhanced instability of mtDNA in comparison to their sensitive counterparts, which is supported by an increased sensitivity of T315I cells to $\mathrm{H}_{2} \mathrm{O}_{2}$. Our results suggest also that NER cannot be involved in the mechanisms of imatinib resistance, as indicated by UV-induced mtDNA damage and its repair in resistant and sensitive cells. In summary, some aspects of mitochondrial mutagenesis can play a role in imatinib resistance in BCRABL1-expressing cells.

\section{Acknowledgements}

This work was supported by grant no 2011/03/B/ NZ2/01396 from National Science Centre, Poland.

The authors thank Dr. A. Piastowska-Ciesielska, Dr. D. Wysokinski, S. Glowacki and P. Czarny for acquisition of some preliminary data.

\section{Conflict of interest statement}

The authors do not declare any conflict of interest.

\section{REFERENCES}

Alexeyev M, Shokolenko I, Wilson G, LeDoux S (2013) The maintenance of mitochondrial DNA integrity - critical analysis and update. Cold Spring Harb Perspect Biol 5: a012641. doi: 10.1101/cshperspect. a012641.Ballinger SW, Van Houten B, Jin GF, Conklin CA, Godley BF (1999) Hydrogen peroxide causes significant mitochondrial DNA damage in human RPE cells. Exp Eye Res 68: 765-772.

Bixby D, Talpaz M (2011) Seeking the causes and solutions to imatinib-resistance in chronic myeloid leukemia. Leukemia 25:7-22. doi: 10.1038/leu.2010.238.

Blasiak J, Hoser G, Bialkowska-Warzecha J, Pawlowska E, Skorski T (2015) Reactive oxygen species and mitochondrial DNA damage and repair in BCR-ABL1 cells resistant to imatinib. BioRes Open Access 4: 334-342. doi: 10.1089/biores.2015.0022.

Brady N, Gaymes TJ, Cheung M, Mufti GJ, Rassool FV (2003) Increased error-prone NHEJ activity in myeloid leukemias is associated with DNA damage at sites that recruit key nonhomologous end-joining proteins. Cancer Res 63: 1798-1805.

Druker BJ (2008) Translation of the Philadelphia chromosome into therapy for CML. Blood 112: 4808-4817. doi: 10.1182/ blood-2008-07-077958.

Gredilla R, Bohr VA, Stevnsner T (2010) Mitochondrial DNA repair and association with aging - an update.ExpGerontol 45: 478488. doi: 10.1016/j.exger.2010.01.017.

Griaud F, Williamson AJ, Taylor S, Potier DN, Spooncer E, Pierce A, Whetton AD (2012) BCR/ABL modulates protein phosphorylation associated with the etoposide-induced DNA damage response. J Proteomics 77: 14-26. doi: 10.1016/j.jprot.2012.06.003.

Hou L, Zhu ZZ, Zhang X, Nordio F, Bonzini M, Schwartz J, Hoxha M, Dioni L, Marinelli B, Pegoraro V, Apostoli P, Bertazzi PA, Bac- carelli A (2010) Airborne particulate matter and mitochondrial damage: a cross-sectional study. Environ Health 9: 48. doi: 10.1186/1476069X-9-48.

Kamenisch Y, Berneburg M (2013) Mitochondrial CSA and CSB: protein interactions and protection from ageing associated DNA mutations. Mech Ageing Dev 134: 270-274. doi: 10.1016/j.mad.2013.03.005.

Kang D, Hamasaki N (2002) Maintenance of mitochondrial DNA integrity: repair and degradation. Curr Genet 41: 311-322.

Kamenisch Y, Fousteri M, Knoch J, von Thaler AK, Fehrenbacher B, Kato H, Becker T, Dollé ME, Kuiper R, Majora M, Schaller M, van der Horst GT, van Steeg H, Röcken M, Rapaport D, Krutmann J, Mullenders LH, Berneburg M (2010) Proteins of nucleotide and base excision repair pathways interact in mitochondria to protect from loss of subcutaneous fat, a hallmark of aging. I Exp Med 207: 379-390. doi: 10.1084/jem.20091834.

Kazachkova N, Raposo M, Montiel R, Cymbron T, Bettencourt C, Silva-Fernandes A, Silva S, Maciel P, Lima M (2013) Patterns of mitochondrial DNA damage in blood and brain tissues of a transgenic mouse model of Machado-Joseph disease. Neurodegener Dis 11: 206-214. doi: 10.1159/000339207.

Kluza J, Jendoubi M, Ballot C, Dammak A, Jonneaux A, Idziorek T, Joha S, Dauphin V, Malet-Martino M, Balayssac S, Maboudou P, Briand G, Formstecher P, Quesnel B, Marchetti P (2011) Exploiting mitochondrial dysfunction for effective elimination of imatinibresistant leukemic cells. PLoS One 6: e21924. doi: 10.1371/journal. pone.0021924.

Koptyra M, Falinski R, Nowicki MO, Stoklosa T, Majsterek I, Nieborowska-Skorska M, Blasiak J, Skorski T (2006) BCR/ABL kinase induces self-mutagenesis via reactive oxygen species to encode imatinib resistance. Blood 108: 319-327.

Lipton JH, Bryden P, Sidhu MK, Huang H, McGarry LJ, Lustgarten S, Mealing S, Woods B, Whelan J, Hawkins N (2015) Comparative efficacy of tyrosine kinase inhibitor treatments in the third-line setting, for chronic-phase chronic myelogenous leukemia after failure of second-generation tyrosine kinase inhibitors. Leuk Res 39: 58-64. doi: 10.1016/j.leukres.2014.10.005

Liu J, Fang H, Chi Z, Wu Z, Wei D, Mo D, Niu K, Balajee AS, Hei TK, Nie L, Zhao YX (2015) PD localizes in mitochondria and protects the mitochondrial genome from oxidative DNA damage. $N u$ cleic Acids Res 43: 5476-5488. doi: 10.1093/nar/gkv472.

Miething C, Feihl S, Mugler C, Grundler R, von Bubnoff N, Lordick F, Peschel C, Duyster J (2006) The Bcr-Abl mutations T315I and $\mathrm{Y} 253 \mathrm{H}$ do not confer a growth advantage in the absence of imatinib. Leukemia 20: 650-657.

Nieborowska-Skorska M, Kopinski PK, Ray R, Hoser G, Ngaba D, Flis S, Cramer K, Reddy MM, Koptyra M, Penserga T, Glodkowska-Mrowka E, Bolton E,Holyoake TL, Eaves CJ, Cerny-Reiterer S, Valent P, Hochhaus A, Hughes TP, van der Kuip H, Sattler M, Wiktor-Jedrzejczak W, Richardson C, Dorrance A, Stoklosa T, Williams DA, Skorski T (2012) Rac2-MRC-cIII-generated ROS cause genomic instability in chronic myeloid leukemia stem cells and primitive progenitors. Blood 119: 4253-4263. doi: 10.1182/ blood-2011-10-385658.

Nieborowska-Skorska M, Flis S, Skorski T (2014) AKT-induced reactive oxygen species generate imatinib-resistant clones emerging from chronic myeloid leukemia progenitor cells. Lenkemia 28: 24162418. doi: 10.1038/leu.2014.249.

Nieborowska-Skorska M, Hoser G, Hochhaus A, Stoklosa T, Skorski T (2013) Anti-oxidant vitamin $E$ prevents accumulation of imatinib-resistant BCR-ABL1 kinase mutations in CML-CP xenografts in NSG mice. Leukemia 27: 2253-2254. doi: 10.1038/leu.2013.123.

Rothfuss O, Gasser T, Patenge N (2010) Analysis of differential DNA damage in the mitochondrial genome employing a semi-long run real-time PCR approach. Nucleic Acids Res 38: e24. doi: 10.1093/ nar/gkp1082.

Schmittgen TD, Livak KJ (2008) Analyzing real-time PCR data by the comparative C(T) method. Nat Protoc 3: 1101-1108.

Skorski T (2002) BCR/ABL regulates response to DNA damage: the role in resistance to genotoxic treatment and in genomic instability. Oncogene 21: 8591-8604.

Slupianek A, Falinski R, Znojek P, Stoklosa T, Flis S, Doneddu V, Pytel D, Synowiec E, Blasiak J, Bellacosa A, Skorski T (2013) BCRABL1 kinase inhibits uracil DNA glycosylase UNG2 to enhance oxidative DNA damage and stimulate genomic instability. Leukemia 27: 629-634. doi: 10.1038/leu.2012.294.

Slupianek A, Hoser G, Majsterek I, Bronisz A, Malecki M, Blasiak J, Fishel R, Skorski T (2002) Fusion tyrosine kinases induce therapeutic drug resistance by stimulation of homology-dependent recombination repair, prolongation of $\mathrm{G} 2 / \mathrm{M}$ phase and protection from apoptosis. Mol Cell Biol 22: 4189-4201.

Synowiec E, Hoser G, Wójcik K, Pawlowska E, Skorski T, Blasiak J (2015) UV differentially induces oxidative stress, DNA damage and apoptosis in BCR-ABL1-positive cells sensitive and resistant to imatinib. Int J Mol Sci 16: 18111-18128. doi: 10.3390/ijms160818111. 